\title{
Evaluating the Long-term Effect of NIST MEP Services on Establishment Performance
}

Link to publication record in Manchester Research Explorer

\section{Citation for published version (APA):}

Lipscomb, C. A., Youtie, J., Arora, S., Shapira, P., \& Krause, A. (2015). Evaluating the Long-term Effect of NIST MEP Services on Establishment Performance. (Working Paper, Center for Economic Studies, U.S. Census Bureau; No. CES 15-09). https://ideas.repec.org/p/cen/wpaper/15-09.html

\section{Citing this paper}

Please note that where the full-text provided on Manchester Research Explorer is the Author Accepted Manuscript or Proof version this may differ from the final Published version. If citing, it is advised that you check and use the publisher's definitive version.

\section{General rights}

Copyright and moral rights for the publications made accessible in the Research Explorer are retained by the authors and/or other copyright owners and it is a condition of accessing publications that users recognise and abide by the legal requirements associated with these rights.

\section{Takedown policy}

If you believe that this document breaches copyright please refer to the University of Manchester's Takedown Procedures [http://man.ac.uk/04Y6Bo] or contact uml.scholarlycommunications@manchester.ac.uk providing relevant details, so we can investigate your claim.

\section{OPEN ACCESS}




\title{
Evaluating the Long-Term Effect of NIST MEP Services on Establishment Performance
}

by

\author{
Clifford A. Lipscomb ${ }^{\text {a,* }}$ \\ Greenfield Advisors
}

\author{
Jan Youtie ${ }^{\text {b }}$ \\ Georgia Institute of Technology
}

\author{
Sanjay Arora ${ }^{b, c}$ \\ Georgia Ins titute of Technology
}

\author{
Andy Krause ${ }^{d}$ \\ Unive rsity of Melbourne \\ Philip Shapira ${ }^{c, e}$ \\ University of Manchester
}

\section{CES 15-09 March, 2015}

The research program of the Center for Economic Studies (CES) produces a wide range of economic analyses to improve the statistical programs of the U.S. Census Bureau. Many of these analyses take the form of CES research papers. The papers have not undergone the review accorded Census Bureau publications and no endorsement should be inferred. Any opinions and conclusions expressed herein are those of the author(s) and do not necessarily represent the views of the U.S. Census Bureau. All results have been reviewed to ensure that no confidential information is disclosed. Republication in whole or part must be cleared with the authors.

To obtain information about the series, see www.census.gov/ces or contact Fariha Kamal, Editor, Discussion Papers, U.S. Census Bureau, Center for Economic Studies 2K132B, 4600 Silver Hill Road, Washington, DC 20233, CES.Papers.List@census.gov. 


\begin{abstract}
This work examines the effects of receipt of business assistance services from the Manufacturing Extension Partnership (MEP) on manufacturing establishment performance. Several measures of performance are considered: (1) change in value-added per employee (a measure of productivity); (2) change in sales per worker; (3) change in employment; and (4) establishment survival. To analyze these relationships, we merged program records from the MEP's client and project information files with administrative records from the Census of Manufacturers and other Census databases over the periods 1997-2002 and 2002-2007 to compare the outcomes and performance of "served" and "unserved" manufacturing establishments. The approach builds on, updates, and expands upon earlier studies comparing matched MEP client and non-client performance over time periods ending in 1992 and 2002. Our results generally indicate that MEP services had positive and significant impacts on establishment productivity and sales per worker for the 2002-2007 period with some exceptions based on employment size, industry, and type of service provided. MEP services also increased the probability of establishment survival for the 1997-2007 period. Regardless of econometric model specification, MEP clients with 1-19 employees have statistically significant and higher levels of labor productivity growth. We also observed significant productivity differences associated with MEP services by broad sector, with higher impacts over the 2002-2007 time period in the durable goods manufacturing sector. The study further finds that establishments receiving MEP assistance are more likely to survive than those that do not receive MEP assistance. Detailed findings of the study, as well as caveats and limitations, are discussed in the paper.
\end{abstract}

\footnotetext{
${ }^{a}$ Greenfield Advisors, 106 N. Bartow Street, Cartersville, GA 30120

${ }^{\mathrm{b}}$ Enterprise Innovation Institute, Georgia Institute of Technology, Atlanta, GA 30308

' School of Public Policy, Georgia Institute of Technology, Atlanta, GA 30332-0345

${ }^{d}$ University of Melbourne, Australia (formerly of Greenfield Advisors)

e Manchester Business School, University of Manchester, Manchester M209PL, UK

* Corresponding Author. E-mail: cliff@greenfieldadvisors.com; Phone: +1 (770) 334-3952
} 


\section{ACKNOWLEDGEMENTS}

The project team gratefully acknowledges the ideas and guidance received from the Technical Advisory Group: Ron Jarmin, U.S. Census Bureau; David Beede, U.S. Department of Commerce; Barbara Fraumeni, Hunan University (China); and Carolyn Heinrich, University of Texas. Additional comments were appreciatively received from Susan Helper and Cassandra Ingram, U.S. Department of Commerce, and Kenneth P. Voytek, NIST-MEP. This project was prepared for NIST-MEP, Contract \# SB1341-11-SE-1446. The findings and observations contained in this report are those of the authors and do not necessarily reflect the views of the Technical Advisory Group or the sponsor (National Institute for Standards and Technology, Manufacturing Extension Partnership). Any opinions and conclusions expressed herein are those of the author(s) and do not necessarily represent the views of the U.S. Census Bureau. All results have been reviewed to ensure that no confidential information is disclosed. 


\section{INTRODUCTION}

This research project examines the effects of rec eipt of business assistance services from the Manufacturing Extension Partnership (MEP) on manufacturing establishment performance. The project seeks to advance previous work on the effect of manufacturing extension services on establishment productivity. Examining the determinants of manufacturing establishment performance is important because U.S. industry continues to face challenges due to the increasingly competitive global business environment. In exploring determinants of establishment productivity, previous work has examined an array of factors, including plant ownership change, technology adoption, and deregulation. This paper adds consideration of business assistance services as a potential productivity determinant, specifically services of the Manufacturing Extension Partnership (MEP) program, which is administered by the National Institute of Standards and Technology (NIST). To gauge the effects of business assistance services, measurement of productivity effects must take place at the establishment level. However, publicly available establishment-level productivity information is not accessible. Therefore, this work assesses the performance of MEPassisted manufacturing establishments by linking establishment-level MEP data on business assistance recipients to establishment-level data from the U.S. Census Bureau.

The methodology used in this paper draws on two prior studies that examined the effect of the MEP program on manufacturing establishment performance. The first study, by Ron Jarmin (1999), was conducted on manufacturing performance data for the 1987 to 1992 period. This time period was prior to the full roll-out of the MEP program in 1999. The second study was performed by a team from SRI International and Georgia Institute of Technology (Georgia Tech) on manufacturing performance data covering the 1997 to 2002 period (Ordowich et al., 2012). Both of these studies assessed the impact of MEP services on manufacturing productivity, sales, and employment grow th. 
This paper extends this body of evaluation studies by using a novel fuzzy logic matching program to confirm that MEP data and Census data are linked to the correct establishment and by updating the analysis with data from the 2002 to 2007 period. In addition, we also analyze establishment survival by testing the ability of establishments to maintain operations from an earlier to a later period. The paper addresses the following questions:

- What impact does MEP assistance have on establishment performance?

- How does this impact vary by establishment size, manufacturing sector, and substance of the specific services provided?

- Are MEP clients more likely to survive than non-clients?

In the section below, we begin with an overview of the MEP program. In Section 3, we summarize the results of the Jarmin (1999) and Ordowich et al. (2012) studies. Section 4 describes the methodology used in this paper, which involved linking information from MEP project and customer information files (PIF/CIF) over the period under analysis and from databases from the U.S. Census Bureau. Section 5 describes the results of our study. Finally, we conclude with some implications of the results.

\section{THE MANUFACTURING EXTENSION PARTNERSHIP}

The MEP program provides business, technology, and other forms of assistance, typically to small and midsize manufacturing establishments. The program deploys a network of manufacturing experts (also known as manufacturing extension agents) with centers in all 50 U.S. states and Puerto Rico. The aim of the MEP program is to strengthen U.S. manufacturing competitiveness. The

program was established through the Omnibus Trade and Competitiveness Act of 1988, which 
created the first three centers, with additional centers added such that a national system was in place by the mid-1990s. ${ }^{1}$

The total MEP annual system budget is about $\$ 300$ million (National Research Council, 2013, p. 19). The federal government awards about one-third of funds for the program, which the centers match from state funds, client fees, and other sources. Over half $(55 \%)^{2}$ of the centers operate as non-profit organizations (under section 501(c)(3) of the Internal Revenue Service code), with the others operating as university-based or state government-run programs. MEP centers deliver services with some mix of in-house specialists and third-party providers. More than 1,400 non-federal staff and over 2,400 third-party service providers are involved in service delivery (National Research Council, 2013, p. 15). MEP services are delivered through assessments, one-onone technical engagements, hosting manufacturing networks, and training events. Currently, the MEP serves about 7,000 to 8,000 clients annually through about 12,000 projects. ${ }^{3}$ NIST MEP oversees the governance structure of the system and maintains an extensive program of monitoring and evaluation.

\section{PRIOR STUDIES OF THE MEP AND MANUFACTURING PERFORMANCE}

A series of studies, using a broad range of methods, have examined various aspects of the performance and impact of the MEP in the U.S. and other technology extension and advisory services outside of the U.S. (For reviews of these studies, see Youtie, 2013; and Shapira and Youtie, 2014.) In this paper, we particularly focus on two earlier benchmark national studies of the effects of

\footnotetext{
${ }^{1}$ For a review of the development and operations of the MEP, see National Research Council (2013).

2 This percentage is based on 58 centers (exduding non-operational centers in Alaska and Florida).

${ }^{3}$ National Research Council (2013, p. 57). According to this study, MEP services peaked most recently in FY 2007, with 9,000 dients served through some 14,500 projects.
} 
the MEP on client performance using non-assisted control groups. These benchmark studies are overviewed in the following two sections.

\subsection{Study 1: Jarmin}

Jarmin (1999) estimated the effect of MEP services on the productivity of establishments. While he initially proposed to look at output and productivity, his final published results are reported only in terms of productivity. This also is the main focus of our analysis, though we look at changes in sales per worker and changes in employment as additional dependent variables as well. Jarmin's analysis was based on an augmented Cobb-Douglas production function with physical capital, employment, and other plant characteristics as shown in the equation below. ${ }^{4}$

$$
Y_{i t}=A e^{\delta E x t_{i t}} K_{i t}^{\beta} L_{i t}^{\eta} e^{\varepsilon_{i t}}
$$

This equation serves as the theoretical basis for all of the analyses that follow. The variables in this equation are defined as follows:

- $\mathrm{Y}_{\mathrm{it}}$ : value-added for establishment $\mathrm{i}$ in period $\mathrm{t}$

- $\mathrm{L}_{\mathrm{it}}$ : employment for establishment $\mathrm{i}$ in period $\mathrm{t}$

- $\mathrm{K}_{\mathrm{it}}$ : book value of the capital stock of plant $\mathrm{i}$ in period $\mathrm{t}$

- $\varepsilon_{i t}$ : error term

- Ext $_{\mathrm{it}}$ : dummy variable that is 1 if plant i received MEP services in period t, 0 otherwise Jarmin began his analysis by performing simple ordinary least squares (OLS) analysis. He then used a Heckman (1976) two-stage model to control for selection bias. The selection model used a dummy variable for whether or not the plant was located in a Metropolitan Statistical Area

\footnotetext{
4 This model is based on the work of Solow (1957) and the augmentation of this function by Griliches (1996) with the stock of research expenditures acamulated by the establishment.
} 
(MSA) that contained a manufacturing extension center as an instrument for the likelihood of being an MEP client. This variable was found to be associated with client standing (Jarmin, 1999, p. 111).

Jarmin specified the Cobb-Douglas production function as a linear regression equation by taking the natural logarithm of the Cobb-Douglas equation and rearranging the results. He obtained the following regression equation:

$$
\Delta \log \left(\frac{Y}{L}\right)_{i}=\alpha+\delta E x t_{i}+\beta \Delta \log \left(\frac{K}{L}\right)_{i}+(\mu-1) \Delta \log (L)_{i}+\varepsilon_{i}
$$

In Equation 2, the deltas $(\Delta s)$ reflect changes in the value of a variable between 1987 and 1992, and the parameter $\mu$ measures deviations from constant returns to scale. The dependent variable in Equation 2 is the percentage change in labor productivity between 1987 and 1992. (Note that in our analyses we have measured changes between 1997 and 2007, 1997 and 2002, as well as 2002 and 2007.) The impact of the MEP program is measured by the parameter $\delta$, which measures the percentage difference in productivity between client and non-client plants. This formulation assumes that receiving MEP services would increase the productivity of a small plant by the same percentage as it would a large plant. Using Equation 2, Jarmin estimated two OLS models, one for all plants $(\mathrm{N}$ $=15,263)$ and one with plants with 19 to 500 employees $(\mathrm{N}=7,782)$.

In addition to estimating the OLS equation above, Jarmin (1999) estimated two more models (using the same plant size delineations) with two-digit standard industrial classification (SIC) dummies to control for industry differences as shown in the equation below.

$$
\Delta \log \left(\frac{Y}{L}\right)_{i}=\alpha+\delta E x t_{i}+\beta \Delta \log \left(\frac{K}{L}\right)_{i}+(\mu-1) \Delta \log (L)_{i}+\lambda_{1 \ldots N} S I C_{i}+\varepsilon_{i}
$$




\subsection{Study 2: Ordowich et al.}

Jarmin faced several limitations. He was only able to measure whether or not an establishment received MEP services between 1987 and 1992. Data on the level and type of treatment were not of sufficient quality for his analyses. Likewise, his study was situated in a period before nationwide establishment of the MEP, when there were only a few centers funded. To extend the Jarmin modeling effort, Ordowich et al. (2012) studied the effect of MEP services on labor productivity and other outcome variables. Their study, originally completed in 2009 and published as

a Census working paper in $2012,{ }^{5}$ used new data to run a number of additional OLS models replacing the binary treatment variable in the equations above $\left(\right.$ Ext $\left._{\mathrm{i}}\right)$ with a variety of other measures. The treatment measures used were:

- Level of treatment

o Number of engagements for each establishment

o Cumulative hours of assistance for each establishment

o Cumulative dollar amount paid by establishments

- Period of treatment (binary for specific years, combinations of years)

o All 1997 through 2002

o Specific years

- Type of treatment

o Delivery mode (project, event)

o Type of assistance (assessment, technical, education)

${ }^{5}$ http:/ /www2.census.gov/ces/wp/2012/CES-WP-12-15.pdf. 
o Substance (business services, quality systems, manufacturing systems, information technology, human resources and organizational development, engineering/technical assistance)

Ordowich et al. (2012) used three databases: one with MEP client engagements occurring between 1997 and 2002, another with demographic information for each client, and a third dataset with MEP center characteristics. While complete data on MEP engagements only dates back to 1999, the Ordowich et al. (Ibid.) study included all data available on MEP engagements between 1997 and 2002 to capture as many MEP clients as possible. Their study found about 47,000 engagements in the MEP database that were delivered to about 20,000 unique establishments between 1997 and 2002. Their modeling approaches included difference-in-differences (DiD) models and lagged dependent variable models to estimate the relationship between manufacturing extension and labor productivity. The DiD model for panel data is:

$$
\Delta \log \left(\frac{Y_{i t}}{L_{i t}}\right)=\Delta \lambda_{t}+\delta \Delta E x t_{i t}+\beta \Delta \log \left(\frac{K_{i t}}{L_{i t}}\right)+(\mu-1) \Delta \log \left(L_{i t}\right)+\Delta \varepsilon_{i t}
$$

The lagged dependent variable model for panel data is:

$$
\log \left(\frac{Y_{i t}}{L_{i t}}\right)=\alpha+\delta E x t_{i t}+\beta \log \left(\frac{K_{i t}}{L_{i t}}\right)+(\mu-1) \log \left(L_{i t}\right)+\theta \log \left(\frac{Y_{i t-1}}{L_{i t-1}}\right)+\varepsilon_{i t}
$$

Their results were mixed and suffered from several data limitations. As discussed in Angrist and Pischke (2009), the ideal situation is to estimate a fixed effects model with a lag term. ${ }^{6}$ How ever, as the Ordowich et al. study correctly pointed out, without stronger assumptions and more data, such a combined model may lead to inconsistent estimates. ${ }^{7}$ In addition, the Ordowich et al. study

\footnotetext{
${ }^{6}$ Angrist and Pischke (2009), p. 245.

7 To estimate a model with both differences and a lag, one must have data from more than two time periods and assume that error terms are only correlated across adjacent time periods.
} 
tried several different instruments based on MEP center locations and other methods to correct for selection bias (such as propensity score matching), but none of these methods was correlated with the likelihood of an establishment being an MEP client in the same way that Jarmin (1999) reported.

This current project builds on the Jarmin and Ordowich et al. studies by examining these relationships across three different years of Census of Manufactures (CMF) data (1997, 2002, and 2007). This broader timeframe enables us to overcome Jarmin's focus on the pre-MEP extension period and Ordowich et al.'s focus on the recession-tainted 1997-2002 time period. Furthermore, this project builds on the results from these two models to bracket the effect of MEP services on labor productivity and output growth. ${ }^{8}$ Additional data from the CMF 2007 survey also allows reestimation of state and industry fixed-effects models first estimated in the Ordowich et al. study.

\footnotetext{
${ }^{8}$ Angrist and Pischke(2009), p.246-247.
} 


\section{DATA AND METHODS}

As discussed above, the study reported in this paper uses the general methodology of combining MEP administrative data from the PIF/CIF with data from the CMF. However, it introduces several extensions and improvements. It extends the analysis to the CMF for 2007, providing an additional period for observing productivity changes. The focus is on establishments that received MEP services between 1997 and 2007 in two time periods: 1997-2002 and 2002-2007.

It is important to keep in mind the broader macro-economic and manufacturing context within which our study is situated. In particular, our two time periods of interest had different grow th trajectories. The 1997-2002 period was one of relatively slower grow th in the manufacturing economy. In current dollars, manufacturing gross domestic product (GDP) had a compound annual grow th rate (CAGR) four times higher in the 2002-2007 period (1.5\%) than in the 1997-2002 period (0.4\%). In constant 2009 dollars, the growth rate for the manufacturing economy was still $64 \%$ higher in the later period (1.4\%) than the earlier period (0.8\%) (Figure 1). 
Figure 1. U.S. Manufacturing Gross Domestic Product by Year

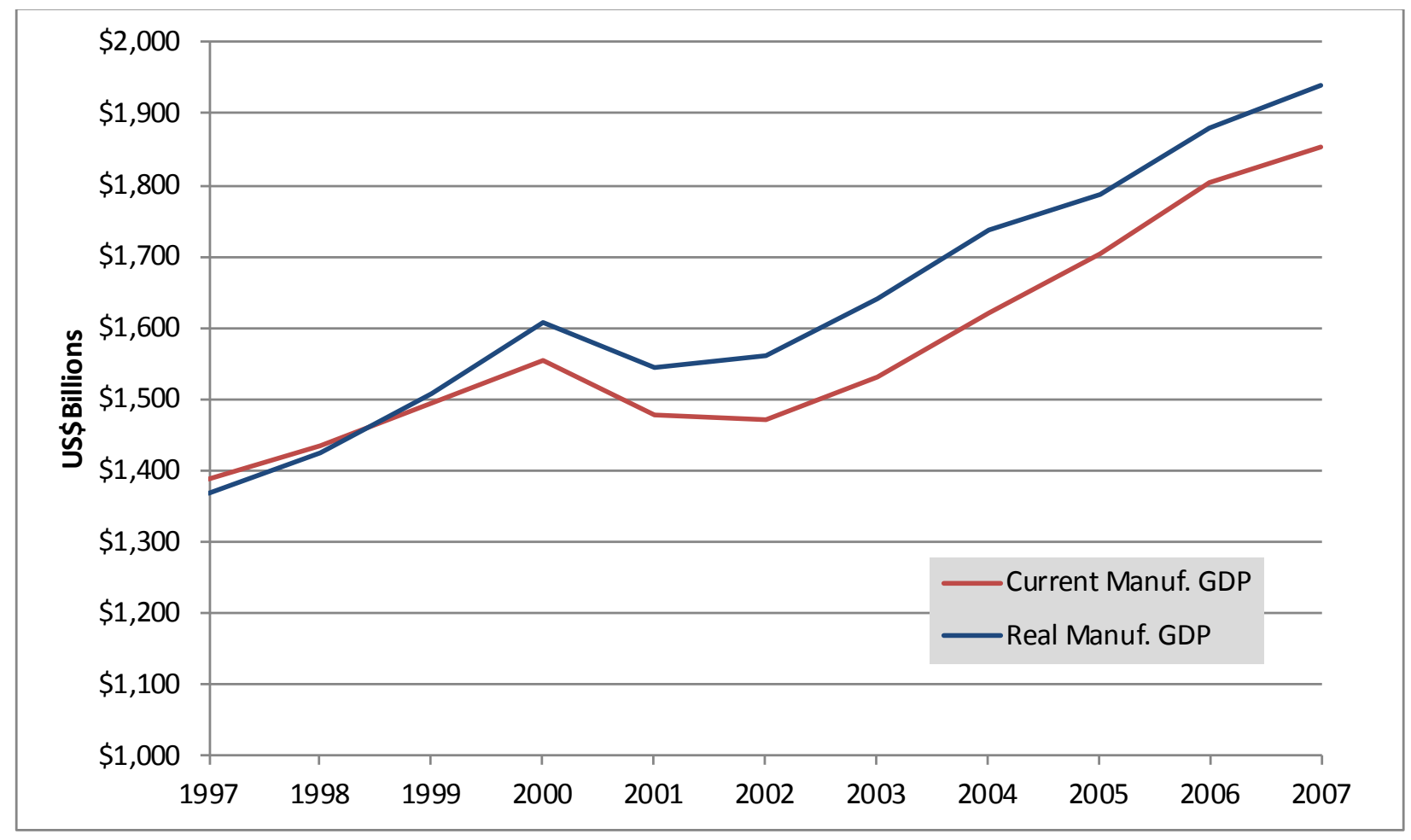

Source: http://www.bea.gov. Real manufacturing GDP in 2009 U.S. Dollars.

This section describes the data sources, data elements, and variables used to carry out the analyses in this paper. The section begins with a listing of data elements in each database considered for use in subsequent analyses. This section then will describe how researchers calculate the variables needed to perform analyses using each of the data elements. The section will then present the models used to estimate establishment outcomes. The unit of analysis for all analyses is the manufacturing establishment. 


\subsection{DATA}

\subsubsection{NIST MEP Program Data}

As an initial step, we processed data on every establishment that received MEP services from 1997 to 2007 from the NIST MEP program. Most of these elements are contained in the NIST MEP Project Information File (PIF). ${ }^{9}$ For each MEP client, we received a record containing the data elements listed below:

- Unique IDs

o For each project/event (PIF: ID) (a project is an engagement with a single client, whereas an event represents training or other services to groups of clients)

o For each client (PIF: Client ID)

- Title of project/event (PIF: Title)

- Period of assistance calculated from:

o Start date (PIF: Start Date)

O End date (PIF: End Date)

- Delivery Mode: project or event (PIF: Delivery Mode)

- Substance of assistance: business services, quality systems, manufacturing systems, information technology, human resources and organizational development, and engineering/technical assistance (PIF: Substance)

- Type of assistance: assessment, technical, education (PIF: Type)

- MEP center staff hours devoted to project/event (PIF: Center Hours)

- Third-party hours devoted to project/event (PIF: Affiliate Hours)

\footnotetext{
${ }^{9}$ Using some of these variables, we created variables to use in our analyses that quantified the total number of engagem ents for each establishment as well as the total number of cum ulative hours of service provided by the MEP center.
} 
- Cost of services to MEP: dollar amount billed to companies (PIF: Total Billed)

- ID of MEP center providing service for each project/event

This project-level information is linked to a customer name in the Customer Information File (CIF) using unique client IDs. The following data items are relevant for our analyses:

- Client name

- Client address

- Number of employees

- NAICS five-digit code

Additional center-level variables that we considered in carrying out our analyses included:

- Year that each center was started

- Number of staff in each center (in median year: 2003)

- Total funding from MEP for each center

- Location of each MEP center (in median year: 2003)

- Market penetration rate for each center

- Type of center: university/501(c)3/state agency

The location of each center and auxiliary locations (e.g., other offices affiliated with the MEP center) was intended to be used to create an instrument for dealing with the problem of "selection bias" (in which higher productivity grow th is a precondition for manufacturers that consider using MEP services). However, this instrument did not resolve the self-selection bias in the models that were estimated. Section 4.3.1 describes the other instruments (year of firm establishment, rurality of the county based on firm address) that were used. The distance from each establishment to the location of the nearest center's headquarters and offices was used as a control variable in the survival analysis model. 
We initially labeled these establishments as manufacturers using the following process: (1) created a non-duplicate establishment name list comprising 61,919 records, 55,834 of which were "non-blank" in the "Name" field; (2) selected all establishments that had received service during the time period under analysis, which reduced the record count to 53,647; (3) separated manufacturing establishments from non-manufacturers based on the former's having NAICS codes in the CIF beginning with 31,32 , or 33 (for those lacking NAICS codes, we looked them up in Dun \& Bradstreet's Million Dollar Database and Reference USA); (4) reviewed the list of manufacturers and removed any that had manufacturing NAICS codes but were clearly not manufacturers (this was a manual process); (5) reviewed the list of non-manufacturers and added back any that appeared to be manufacturers (this also was a manual process, which found a particular clustering of what were actually manufacturers identified as having the NAICS code of "11111"); and (6) linked the resulting list to the PIF data about MEP projects. The resulting database had 38,067 manufacturers served from 1997 to 2007 that received an average of 3.3 project-based assists over this time period.

\subsubsection{Census Administrative Data}

For this project, researchers accessed three databases through the Census Research Data Center (RDC) in Atlanta, Georgia, after securing approval from the U.S. Census Bureau and the Internal Revenue Service (IRS) to proceed with this study. These databases were the Standard Statistical Establishment Listing (SSEL), Longitudinal Business Database (LBD), and the Census of Manufactures (CMF). Because 1997 is the first year of our study, North American Industrial Classification System (NAICS) codes were used and there was no need for Standard Industrial Classification (SIC) code information for establishments. The Annual Survey of Manufactures (ASM) also was not used because small and midsize manufacturers are not fully represented in this database. 


\subsubsection{Standard Statistical Establishment Listing (SSEL) and Matching}

The SSEL contained many data elements for all establishments listed in the Business Register (BR). For this project, the following data elements for all establishments listed in the Business Register between 1997 and 2007 were used:

$\begin{array}{ll}\text { Variables from Standard Statistical Establishment Listing (SSEL): 1997-2007 } \\ \text { Variable: } & \text { Description: } \\ \text { CFN } & \text { Census File Number (contains EIN) } \\ \text { EIN } & \text { Employer Identification Number } \\ \text { LFO } & \text { Legal Form of Organization } \\ \text { IND } & \text { Industrial Classification (NAICS) } \\ \text { ST } & \text { State } \\ \text { COU } & \text { County } \\ \text { NM } & \text { Business Name } \\ \text { ADD } & \text { Mailing Address } \\ \text { ZIP } & \text { ZIP Code }\end{array}$

The project linked Census Bureau data to the MEP business assistance recipients. This was done using fuzzy logic code in the R programming software to match each establishment in the MEP data set to a unique establishment identifier in the SSEL. Generally, the researchers removed certain characters, such as commas, ampersands, slashes, and periods to leave only letters in the address field. Then, after standardizing common features such as "street", which may appear as "St." or "Street" or "St", as well as other features such as "road" and "avenue", the algorithm sought matches on combinations of establishment name and address to obtain the highest quality and number of matches. The $\mathrm{R}$ matching code enabled real-time review of individual matches. This process took from April 2014 to August 2014. During our review process, we observed that any record with a fuzzy matching score below $90 \%$ was likely not a true match. This high, but accurate, threshold resulted in a match rate of 20\% (approximately 7,500 establishments). This match rate is similar to that in the Ordowich et al. study in terms of the number of MEP client establishments (7,737 MEP client establishments) that were matched in both the LBD and the CMF datasets. 
Indeed, after a visual inspection of the matched data at the $90 \%$ and lower scores, we are very comfortable with the quality of the matches using the $90 \%$ score as the threshold vis-à-vis some other score threshold. Nevertheless, we acknowledge that it is highly likely that unmatched MEP clients exist in the control group (non-MEP clients), which means our results would be biased towards zero.

As we expected, the employment size distributions differed between matched and unmatched MEP clients. Specifically, 71\% of matched MEP clients fell into three employment categories (20-99, 100-249, and 250-499) while unmatched clients were more concentrated among smaller establishments, particularly the 1-19 employment category. We subsequently used the unique establishment identifiers in each file (i.e., the Census file number and LBD number) to link the MEP business assistance records to the CMF and LBD data sets. Table 1 shows the distribution of MEP clients and non-clients, from the pool of matched establishments, across different employment size categories as well as the distribution of MEP clients across employment size categories before any matching occurred. This shows that the matching rates were similar across employment size categories, meaning that the matching algorithm did not discriminate in favor of any particular size of establishments.

Table 1. Distribution of Matched MEP Clients and Non-Clients by Employment Size (2007)

\begin{tabular}{lcc|c}
\hline Employment Size Category & $\begin{array}{c}\text { Matched } \\
\text { MEP Clients }\end{array}$ & Non-Clients & Raw MEP Records \\
\hline 1 to 19 employees & $25 \%$ & $70 \%$ & $31 \%$ \\
20 to 99 employees & $46 \%$ & $22 \%$ & $37 \%$ \\
100 to 249 employees & $19 \%$ & $6 \%$ & $18 \%$ \\
250 to 499 employees & $6 \%$ & $2 \%$ & $9 \%$ \\
500 or more employees & $4 \%$ & $1 \%$ & $5 \%$ \\
\hline
\end{tabular}


Note: MEP clients, N > 7,500; Non-MEP clients $\mathrm{N}>300,000$; MEP records $\mathrm{N}=39,349$

\subsubsection{Census of Manufactures}

The CMF includes all establishments in the manufacturing sector in years ending with a 2 and a 7. The most recent CMF data available for analysis at the Census Bureau at the time of our initial proposal to the Census Bureau were from the 2007 Census. Our analyses used data from the 1997, 2002, and 2007 CMF. The key variables obtained from the CMF and used in this analysis are:

$\begin{array}{ll}\text { Variables from Census of Manufactures (CMF): 1997, 2002, } 2007 \\ \text { Variable: } & \text { Description: } \\ \text { CFN } & \text { Census File Number (contains EIN) } \\ \text { EIN } & \text { Employer Identification Number } \\ \text { LFO } & \text { Legal Form of Organization } \\ \text { IND } & \text { Industrial Classification (NAICS) } \\ \text { ST } & \text { State } \\ \text { COU } & \text { County } \\ \text { TE } & \text { Total Employment } \\ \text { PW } & \text { Number of Production Workers } \\ \text { TVS } & \text { Total Value of Shipments } \\ \text { VA } & \text { Value-Added } \\ \text { TCE } & \text { Total Capital Expenditures } \\ \text { SW } & \text { Salaries and Wages }\end{array}$

The primary use of the CMF data was to provide key information on the establishments that was needed for the analysis, such as total employment (full-time equivalent or FTE), number of production workers, value-added, and capital expenditures (used in the capital to labor ratio). To meet Census Bureau disclosure requirements, the TVS variable was kept to conduct all disclosure analyses to enable release of the results from the Atlanta Census Research Data Center (RDC).

\subsubsection{Longitudinal Business Database}

The LBD comprises information to enable access to prior CMFs. This database was used to link to information from CMFs in 1997, 2002, and 2007. The project also used the LBD to link establishments across time to analyze survival as well as changes in key variables (such as sales 
grow th), to obtain a measure of the establishment's age, and to identify establishments that are part of single-unit or multi-unit firms. 


\begin{tabular}{|c|c|}
\hline \multicolumn{2}{|c|}{ Variables from Longitudinal Business Database (LBD) } \\
\hline Variable: & Description: \\
\hline CFN & Census File Number (contains EIN) \\
\hline EIN & Employer Identification Number \\
\hline LDBNUM & Longitudinal Database Number \\
\hline FIRSTYEAR & First Year Establishment Is Observed \\
\hline FLAGB & Birth, Death, Continuer Link Flag \\
\hline LAST YEAR & Last Year Establishment Is Observed \\
\hline MU & Single-Multi Unit Identifier \\
\hline
\end{tabular}

Figure 2 illustrates the linkages between these datasets.

Figure 2. Datasets and Links

\subsection{VARIABLES}

The information in these MEP and Census Bureau databases was used to calculate variables to be used in our analyses. These variables are classified as either outcome, treatment, or control 
variables. Each variable and how it was calculated is described in Appendix 1. All dollar values were converted into 2007 dollars using the Consumer Price Index (CPI-U) for All Urban Consumers.

\subsection{MODELS}

Our analyses examine changes in productivity as a function of other variables and MEP assistance. The general approach is to replicate and enhance the analysis of the effect of MEP services on establishments performed by Jarmin (1999) and Ordowich et al. (2012). In doing so, we encountered many of the same issues, including selection bias, the possibility of different methodologies giving us mixed results, limited time coverage, an overemphasis on quantitative measures of productivity, sales, and employment that do not fully capture the effect of MEP in recessionary or slow economic growth periods. In addition to replicating the prior analyses, we performed new analyses (e.g., survival analysis) and considered additional CMF data (2007) that had been previously unavailable. The models we utilize in this evaluation are described below.

\subsubsection{Controlling for Selection Bias}

Generally, several interrelated issues need to be addressed when evaluating the effect of MEP services on establishment outcomes. First, establishments are likely more heterogeneous in terms of their characteristics than can be captured by a single-line ordinary least squares (OLS) regression equation. Second, selection bias occurs because establishments are not randomly assigned to the treatment and control groups; establishments select whether or not to become MEP clients. Jarmin (1999) found that companies with high sales growth but lower than average productivity selfselect into the group of MEP clients. 
To control for self-selection bias, both Jarmin (1999) and Ordowich et al. (2012) used a Heckman two-stage model, which is also commonly referred to as an instrumental variables (IV) approach. For his instrument, Jarmin (1999) used a dummy variable to indicate whether or not an establishment is in an MSA with a manufacturing extension center. Ordowich et al. (2012) used a similar variable. The instrument was successful at controlling for self-selection bias in the Jarmin (1999) study (as it was correlated with client standing), but not in the Ordowich et al. (2012) study.

The current study also estimates an instrumental variable model using the age of the establishment and the 2003 USDA-ERS Rural-Urban Continuum Code (Rurality) as instruments. The latter instrument ranges from 1 (counties with $1+$ million population) to 9 (completely rural counties with less than 2,500 population, not adjacent to a metro area). These instruments are correlated with the likelihood of an establishment being a client but are not correlated with labor productivity growth. In early testing, we also considered distance to the nearest MEP center as an instrument, but that variable failed to control for self-selection bias as it did not sufficiently distinguish client standing. We did use this variable in the survival analysis model to account for center effects based on distance from the closest MEP office alone. Table 2 shows, for matched establishments, the distribution of MEP clients and non-clients across the various rurality classifications. 
Table 2. Matched Establishments, by MEP Clients and Non-Clients, Across the 2003 USDA-ERS Rural-Urban Continuum Codes

\begin{tabular}{|c|c|c|c|}
\hline $\begin{array}{l}\text { Continuum } \\
\text { Code }\end{array}$ & Description & $\begin{array}{c}\text { Did Not } \\
\text { Receive MEP } \\
\text { Services }\end{array}$ & $\begin{array}{c}\text { Did Receive } \\
\text { MEP } \\
\text { Services }\end{array}$ \\
\hline 1 & $\begin{array}{l}\text { Counties in metro areas of } 1 \text { million } \\
\text { population or more }\end{array}$ & $53 \%$ & $39 \%$ \\
\hline 2 & $\begin{array}{l}\text { Counties in metro areas of } 250,000 \text { to } \\
1 \text { million population }\end{array}$ & $18 \%$ & $24 \%$ \\
\hline 3 & $\begin{array}{l}\text { Counties in metro areas of fewer than } \\
250,000 \text { population }\end{array}$ & $9 \%$ & $12 \%$ \\
\hline 4 & $\begin{array}{l}\text { Urban population of } 20,000 \text { or more, } \\
\text { adjacent to a metro area }\end{array}$ & $5 \%$ & $8 \%$ \\
\hline 5 & $\begin{array}{l}\text { Urban population of } 20,000 \text { or more, } \\
\text { not adjacent to a metro area }\end{array}$ & $2 \%$ & $3 \%$ \\
\hline 6 & $\begin{array}{l}\text { Urban population of } 2,500 \text { to } 19,999 \text {, } \\
\text { adjacent to a metro area }\end{array}$ & $6 \%$ & $8 \%$ \\
\hline 7 & $\begin{array}{l}\text { Urban population of } 2,500 \text { to } 19,999 \text {, } \\
\text { not adjacent to a metro area }\end{array}$ & $3 \%$ & $5 \%$ \\
\hline 8 & $\begin{array}{l}\text { Completely rural or less than } 2,500 \\
\text { urban population, adjacent to a metro } \\
\text { area }\end{array}$ & $1 \%$ & $1 \%$ \\
\hline 9 & $\begin{array}{l}\text { Completely rural or less than } 2,500 \\
\text { urban population, not adjacent to a } \\
\text { metro area }\end{array}$ & $1 \%$ & $1 \%$ \\
\hline
\end{tabular}

Note: Cells are rounded, therefore columns may not sum to $100 \%$. Although 2013 codes are available, we used 2003 codes because they fell within the time frame of our analysis.

In preliminary analyses, the Heckman correction for selection bias produced mixed results. For the DiD regression model that examined productivity differences between 2002 and 2007, the Heckman correction did not produce more efficient estimates, and the resulting OLS regression model is presented below. However, for the DiD regression model estimated on the 1997 to 2002 period, the Heckman correction did produce more efficient estimates, but the coefficient on extension services was negative and significant, which is consistent with the Ordowich et al. (2012) study's finding. 
In summary, although we anticipated finding instruments that would control for selection bias, we had mixed success in doing so. Drawing on prior instruments used to control for selection bias, as well as using other instruments in this study, we were unable to find a single instrument that controlled for selection bias across all of the years in the study. Future research could make progress on this part of the analysis by trying additional instruments, including instruments built on served and unserved establishments in the same firm or enterprise group. Nonetheless, we proceed with this study by estimating the impact of the variable of interest, receipt of MEP assistance, on productivity growth measures in an OLS framework.

\subsubsection{Difference-in-Differences (DiD) Model}

First, we replicated the DiD model in the Ordowich et al. (2012) study by re-estimating Equation 4. This model controls for time-invariant characteristics of each establishment. This includes both observable factors such as industry and location as well as unobservable factors such as management ability (Mundlak, 1961). This model is estimated for two changes in productivity (1997-2002, 2002-2007) for the set of continuing establishments as well as subsets of the data, including five different employment groups as well as different NAICS sectors. For establishments that survive through all three periods, this analysis tells us the differential impact of being served by the MEP in one of these two 5-year periods. We also consider productivity differences by employment size, industry, and substance of assistance and report on the use of instruments to address selection bias. 


\subsubsection{Lagged Dependent Variable (LDV) Model}

Second, we replicated the lagged dependent variable model that was also used in the Ordowich et al. (2012) study by re-estimating Equation 5. With this model, variation in labor productivity in a given time period is expressed as a function of contemporaneous capital to labor ratios, contemporaneous employment, and labor productivity in a previous period. This model is estimated to show the degree to which estimates of the impact of MEP assistance on establishment productivity are validated by a different modeling approach.

\subsubsection{Survival Analysis Models}

Survival analysis seeks to provide information on the factors that influence whether or not establishments survive from one period to the next. Survival analysis has been used to study a range of effects, from student attrition rates in universities to firm attrition rates from year to year. The basic goal is to estimate the shape of the hazard function for the underlying survival process of, in this research, manufacturing firms. We used two different models (Cox proportional hazards model and logit model) to test whether the receipt of MEP services increases the likelihood of survival from one time period to another.

In this study we tested very specific hypotheses about the characteristics of establishments that survive from period to period using the Cox proportional hazards model, with one of those characteristics being whether or not an establishment received MEP services. The Cox proportional hazards model requires the creation of two special variables: 1) a duration variable denoting the length of time a firm used MEP services (in years) and 2) a dichotomous variable denoting whether the endpoint is censored or not. CENSORED $=0$ if the firm continued to use MEP services by 2007 or CENSORED $=1$ if the firm stopped using MEP services by 2007. One limitation of using 
data in this format is that we cannot analyze "time-varying covariates" as a researcher might do using panel data.

The Cox model estimates a hazard function $h_{i}(t)=h_{0}(t) \exp \left(\beta_{1} x_{1}+\ldots+\beta_{k} x_{k}\right)$, where $i$

references each firm observation and $h_{0}(t)$ is the baseline hazard (that measures the value of the hazard function common to each firm before the other risk factors $x$ are taken into account). The hazard function can be rewritten in its familiar log form:

$$
\log h_{i}(t)=\log h_{0}(t)+\beta_{1} x_{1}+\ldots+\beta_{k} x_{k}
$$

In essence, this function tells us the aspects of firms that make an exit from the sample more or less likely in a given time interval. Using the method of maximum likelihood, the Cox model maximizes the Hosemer and Lemeshow (1989) partial log-likelihood function:

$$
L=\sum_{j=1}^{D}\left[\sum_{k \in D_{j}} x_{k} \beta-d_{j} \ln \left\{\sum_{i \in R_{j}} \exp \left(x_{i} \beta\right)\right\}\right]
$$

The second model we used to test the likelihood of survival is the logit model, which estimates the probability of survival from one period to the next conditioned on a set of predictor variables. Mathematically, the logit model is written in its most familiar form as $=\frac{e^{\alpha+\beta X}}{1+e^{\alpha+\beta X}}$. For both the Cox model and the logit model, the dependent variable is coded $(0,1)$, where 0 indicates establishment survival between the two periods and 1 indicates an establishment's death. This operationalization, while counterintuitive compared to traditional OLS structures, is typical of survival analyses and facilitates the interpretation of odds ratios less than one in the Cox model as establishments having a lower probability of death, ceteris paribus. In the logit model, this operationalization facilitates the interpretation of an establishment's probability of death as increasing (positive coefficient) or decreasing (negative coefficient). 


\section{RESULTS}

Our results begin with descriptive statistics of the primary variables used in the analysis. These are presented in Table 3. Note that the number of observations is rounded to the nearest thousand to satisfy Census Bureau disclosure requirements. ${ }^{10}$

\section{Table 3. Descriptive Statistics}

\begin{tabular}{lccc}
\hline & $\begin{array}{c}\text { Number of } \\
\text { Observations }\end{array}$ & Mean & $\begin{array}{c}\text { Standard } \\
\text { Deviation }\end{array}$ \\
\hline Value-Added Per Employee, 2002 & 360,000 & 98 & 645 \\
Value-Added Per Employee, 2007 & 339,000 & 110 & 506 \\
Sales Per Production Worker, 2002 & 356,000 & 306 & 2,718 \\
Sales Per Production Worker, 2007 & 335,000 & 354 & 1,905 \\
MEP Client (Yes/No) & 654,000 & 0.01 & 0.1 \\
Distance to Nearest MEP Center & 542,000 & 51 & 65 \\
Establishment Age & 452,000 & 19 & 11 \\
Number of Production Workers, 2002 & 371,000 & 29 & 209 \\
Number of Production Workers, 2007 & 345,000 & 30 & 904 \\
Capital to Labor Ratio, 2002 & 356,000 & 19 & 4,865 \\
Capital to Labor Ratio, 2007 & 335,000 & 12 & 214 \\
Rural-Urban Continuum Code & 651,000 & 2.26 & 1.91 \\
\hline
\end{tabular}

Next, we conducted difference of means tests (using the student's t-statistics) of the differences in value-added, employment, and productivity between MEP clients and non-clients. MEP-assisted manufacturing establishments had higher levels of value-added and employment than non-clients (Table 4). These differences were significant at $\mathrm{p}<.05$ with the exception of valueadded per employee in 2002 and 2007.

\footnotetext{
${ }^{10}$ Some tabular and model details in subsequent parts of this section were not able to be released through the disdosure process. These are summarized in more general models or in text only.
} 
Table 4. Difference of Means Test Results

\begin{tabular}{lrrrrrrrrr}
\hline \multicolumn{1}{c}{$\begin{array}{c}\text { MEP Client } \\
\quad \text { Status }\end{array}$} & \multicolumn{3}{c}{ Value-Added (VA) } & \multicolumn{3}{c}{ Employment (TE) } & \multicolumn{3}{c}{ Value-Added per } \\
Employee (VA/EE) \\
Year & 1997 & 2002 & 2007 & 1997 & 2002 & 2007 & 1997 & 2002 & 2007 \\
Non-MEP Client & $\$ 4,759$ & $\$ 5,375$ & $\$ 8,120$ & 43 & 43 & 43 & $\$ 88$ & $\$ 101$ & $\$ 125$ \\
MEP Client & $\$ 13,087$ & $\$ 14,645$ & $\$ 21,185$ & 121 & 112 & 111 & $\$ 106$ & $\$ 114$ & $\$ 133$ \\
\hline T-statistic & -11.83 & -11.41 & -9.74 & -27.07 & -6.82 & -3.32 & -7.06 & -1.48 & -1.04 \\
$\begin{array}{l}\text { Prob. (2-tail test) } \\
\text { N(mepcust=0)- }\end{array}$ & 0.00 & 0.00 & 0.00 & 0.00 & 0.00 & 0.00 & 0.00 & 0.13 & 0.29 \\
$\quad$ rounded & 392,000 & 349,000 & 294,000 & 395,000 & 365,000 & 339,000 & 392,000 & 348,000 & 293,000 \\
$\begin{array}{c}\text { N(mepcust=1) - } \\
\quad \text { rounded }\end{array}$ & 5000 & 5600 & 4900 & 5100 & 5800 & 5000 & 5100 & 5600 & 4900 \\
\hline
\end{tabular}

Note: MEP clients, $\mathrm{N}>7,000$; Non-MEP clients $\mathrm{N}>300,000$.

\subsection{DiD Model}

We replicated the DiD model used by Jarmin and Ordowich et al. over the 1997-2002 and 2002-2007 time periods. The specific model we used included more covariates than Equation 6. Specifically, we included controls for the age of the establishment and two industry class dummy variables to represent durables and nondurables based on these establishments' NAICS codes. The results show a positive but statistically insignificant coefficient for the extension variable in the 2002-2007 period (Table 5). ${ }^{11}$ Other significant predictors of the change in logged value-added per employee (VA/EE) are the capital to labor ratio, the number of production workers, establishment age, and whether an establishment is located in a more urban or rural county.

\footnotetext{
${ }^{11}$ In interpreting this statistically insignificant result, the potential bias of results resulting from the match rate should be kept in mind.
} 
Table 5. DiD Regression Results, 2002-2007

\begin{tabular}{|c|c|c|c|c|}
\hline \multirow[b]{2}{*}{ Variable Name } & \multicolumn{2}{|c|}{$\begin{array}{c}\text { DV = Change in } \\
\ln (\text { Value-Added Per } \\
\text { Employee })\end{array}$} & \multicolumn{2}{|c|}{$\begin{array}{c}\text { DV = Change in } \\
\ln (\text { Sales Per Production } \\
\text { Worker) }\end{array}$} \\
\hline & $\begin{array}{l}\text { Coefficient } \\
\text { Estimate }\end{array}$ & $\begin{array}{l}\text { T-statistic } \\
\text { (prob.) }\end{array}$ & $\begin{array}{l}\text { Coefficient } \\
\text { Estimate }\end{array}$ & $\begin{array}{c}\text { T-statistic } \\
\text { (prob.) }\end{array}$ \\
\hline & & 14.77 & & 53.94 \\
\hline Constant & 0.07 & $(0.00)$ & 0.23 & $(0.00)$ \\
\hline Change in $\ln$ (Capital to Labor & & 68.92 & & 105.09 \\
\hline Ratio) & 0.09 & $(0.00)$ & 0.13 & $(0.00)$ \\
\hline Change in $\ln ($ Number of & & -46.59 & & -111.73 \\
\hline Production Workers) & -0.13 & $(0.00)$ & -0.34 & $(0.00)$ \\
\hline & & -14.19 & & -43.92 \\
\hline Establishment Age & -0.002 & $(0.00)$ & -0.006 & $(0.00)$ \\
\hline & & 3.84 & & 6.54 \\
\hline Rural-Urban Continuum Code & 0.003 & $(0.00)$ & 0.004 & $(0.00)$ \\
\hline MEP Customer (Yes/No) & 0.01 & $\begin{array}{c}1.07 \\
(0.28)\end{array}$ & 0.026 & $\begin{array}{c}3.00 \\
(0.00)\end{array}$ \\
\hline $\begin{array}{l}\text { No. of Observations } \\
\text { (rounded) }\end{array}$ & \multicolumn{2}{|c|}{173,000} & \multicolumn{2}{|c|}{175,000} \\
\hline R-Squared & \multicolumn{2}{|c|}{0.07} & \multicolumn{2}{|c|}{0.28} \\
\hline F-statistic & \multicolumn{2}{|c|}{1,759} & \multicolumn{2}{|c|}{6,295} \\
\hline
\end{tabular}

We validated these results by using the same independent variables to explain variation in two different dependent variables: changes in the logged sales per production worker and changes in employment. We found a significant and positive impact of the extension variable on the natural log of sales per production worker, ceteris paribus (Table 5). Also, we found a statistically significant and positive impact of MEP assistance on the natural log of employment (results not released). When we estimated the same model for the 1997-2002 period, we observed similar results as the Ordowich et al. (2012) paper reported (that productivity was statistically significant and lower for MEP customers). In sum, the se findings suggest a level of consistency that enhances the reliability of their DiD results. 
Next, we tested the hypothesis of whether the sign and significance of the extension variable vary by the size or subsector of the manufacturing establishment. We estimated the same model specification across various subsets of our data. First, we divided establishments into the following size classes: Group $1=1$ to 19 employees; Group $2=20$ to 99 employees; Group $3=100$ to 249 employees; Group $4=250$ to 499 employees; and Group $5=500$ or more employees. Table 6 shows the impact of the extension variable on value-added per employee across the various groups based on total number of employees. The extension variable shows mixed results at this level of

Table 6. DiD Regression Results, by Employment Category, 2002-2007

DV $=$ Change in $\ln$ (Value-Added Per Employee $)$

\begin{tabular}{lcccccc}
\hline & $\begin{array}{c}\text { All } \\
\text { Groups }\end{array}$ & $\mathbf{1 - 1 9}$ & $\mathbf{2 0 - 9 9}$ & $\mathbf{1 0 0 - 2 4 9}$ & $\mathbf{2 5 0 - 4 9 9}$ & $\begin{array}{c}\text { 500 or } \\
\text { more }\end{array}$ \\
\hline No. of Observations & & & & & & \\
(Rounded) & 173,000 & 99,000 & 50,000 & 16,000 & 5,000 & 3,000 \\
MEP coeff estimate & 0.011 & 0.030 & 0.003 & -0.063 & -0.072 & 0.002 \\
T-statistic & 1.07 & 1.20 & 0.26 & -2.85 & -1.89 & 0.05 \\
\hline
\end{tabular}

disaggregation. These results can be loosely interpreted as MEP services having the greatest effect on productivity for smaller establishments with, presumably, fewer other alternative activities (e.g., other consulting activities, other activities aimed at increasing productivity) that affect outcomes. By contrast, larger manufacturers likely have other influences on manufacturing performance that could crowd out the effects of MEP services.

To examine differences by industry group, we divided establishments into a Durables subgroup (NAICS 33 sector) and a Non-Durables subgroup (NAICS 31 and 32 sectors). Based on the durable/non-durable bifurcation, we found significant differences in the impact of MEP assistance on productivity. Specifically, the coefficient on the extension variable (MEP assistance) was positive and significant at the $95 \%$ level of confidence for durables manufacturers and negative 
and insignificant, at the same confidence level, for non-durables (Table 7). These results suggest that MEP clients in the durables manufacturing industry have significant and positive productivity changes across the 2002 to 2007 time period.

Table 7. DiD Regression Results, 2002-2007, by NAICS Industries

$\mathrm{DV}=$ Change in $\ln ($ Value-Added Per Employee $)$

\begin{tabular}{|c|c|c|c|c|}
\hline \multirow[b]{2}{*}{ Variable Name } & \multicolumn{2}{|c|}{$\begin{array}{c}\text { Non-Durable } \\
\text { (NAICS } 31 \text { and 32) }\end{array}$} & \multicolumn{2}{|c|}{$\begin{array}{c}\text { Durable } \\
\text { (NAICS 33) }\end{array}$} \\
\hline & $\begin{array}{l}\text { Coefficient } \\
\text { Estimate } \\
\end{array}$ & $\begin{array}{c}\text { T-statistic } \\
\text { (prob.) }\end{array}$ & $\begin{array}{l}\text { Coefficient } \\
\text { Estimate }\end{array}$ & $\begin{array}{c}\text { T-statistic } \\
\text { (prob.) }\end{array}$ \\
\hline Constant & 0.08 & $11.10(0.00)$ & 0.06 & $9.69(0.00)$ \\
\hline Change in $\ln (\mathrm{K} / \mathrm{L})$ & 0.10 & $48.15(0.00)$ & 0.09 & $49.02(0.00)$ \\
\hline Change in $\ln (\mathrm{PW})$ & -0.16 & $-34.83(0.00)$ & -0.11 & $-30.94(0.00)$ \\
\hline EstabAge & -0.003 & $-11.42(0.00)$ & -0.001 & $-8.48(0.00)$ \\
\hline Continuum Code & 0.004 & $3.42(0.00)$ & 0.002 & $1.93(0.00)$ \\
\hline MEP Customer & -0.029 & $-1.65(0.10)$ & 0.03 & $2.42(0.02)$ \\
\hline $\begin{array}{l}\text { No. of Observations } \\
\text { (rounded) }\end{array}$ & 78,000 & & 95,000 & \\
\hline R-Squared & 0.08 & & 0.06 & \\
\hline F-statistic & 924 & & 850 & \\
\hline
\end{tabular}

We also examined differences in manufacturing productivity based on the type of manufacturing assistance provided. We grouped MEP substance codes into two categories to reflect a "top-line" (sales increasing) orientation versus a "bottom-line" (cost savings) orientation. The "top-line" substance group comprises business services and engineering/technical services; the "bottom-line" substance group comprises quality systems, manufacturing systems, information technology, and human resources and organizational development. We acknowledge that some bottom-line activities may spillover into the top-line activities and vice versa. However, because of the breadth of the substance codes used in the PIF, we judged that the se groupings best proxy the differences in the two orientations. We subsequently weighted these two categories by the number 
of hours of effort associated with engagements in these categories and normalized the results by dividing by the total number of hours. We use this method to account for the common situation where MEP clients receive multiple types of services over the course of the period under study. Thus, the variable reflects the emphasis of the service in one substance category (versus another substance category) rather than a binary condition of selecting into (or not selecting into) a single substance code.

We then incorporated these variables into the DiD regression model covering the 20022007 time period in lieu of the extension variable. The "top-line" substance variable had a positive and statistically significant impact on the change in value-added per employee; the "bottom-line" variable had a negative and statistically insignificant impact on the change in value-added per employee. These results are not inconsistent with what might be expected. Although "bottom-line" assistance contributes to reducing the cost of goods and services, which is a component of valueadded, "top-line" assistance may augment the sales component of value-added more directly.

\subsection{LDV Model}

To validate the results of the DiD model, we also estimated the LDV model as was done in the Ordowich et al. (2012) study. The same covariates used in the DiD model were used in the LDV model, with the lagged version of the dependent variable being the only additional independent variable used in the model. For example, when the dependent variable is the natural log of labor productivity for 2002, the lagged variable is the natural log of labor productivity for 1997. In the other model for the 2002-2007 period, the dependent variable is the natural log of labor productivity for 2007 and the lagged variable is the natural log of labor productivity for 2002 . 
The results of the LDV model are fairly consistent with those of the DiD model and are displayed in Table 8. Generally, in the LDV model spanning 1997-2002, MEP clients have statistically significant and positive productivity levels compared to non-clients overall (across all employment groups) and for the smallest employment levels (1 to 19 employees). This result is consistent with the Ordowich et al. evaluation done across the same time period.

For the period spanning 2002-2007, the LDV model suggests that MEP clients have statistically significant and positive productivity levels compared to non-clients for the 1-19 employee establishments; however, the sign on the MEP assistance variable changes to negative (while remaining statistically significant) for employment groups 100-249 and 250-499 employees. These results are quite consistent with the results of the DiD model results displayed in Table 6. 
Table 8. LDV Regression Results, by Employment Category, 1997-2002 and 2002-2007 $\mathrm{DV}=$ Change in $\ln$ (Value-Added Per Employee $)$

\begin{tabular}{lcccccc}
\hline 1997-2002 & $\begin{array}{c}\text { All } \\
\text { Groups }\end{array}$ & $\mathbf{1 - 1 9}$ & $\mathbf{2 0 - 9 9}$ & $\mathbf{1 0 0 - 2 4 9}$ & $\mathbf{2 5 0 - 4 9 9}$ & $\begin{array}{c}\mathbf{5 0 0} \text { or } \\
\text { more }\end{array}$ \\
\hline No. of Observations (Rounded) & 186000 & 120000 & 48000 & 13000 & 4000 & 3000 \\
MEP coeff estimate & 0.019 & 0.053 & 0.012 & -0.012 & 0.004 & -0.002 \\
T-statistic & 2.330 & 3.290 & 1.080 & -0.670 & 0.130 & -0.060 \\
& & & & & & \\
\hline 2002-2007 & & & & & & \\
No. of Observations (Rounded) & 186000 & 107000 & 55000 & 16000 & 5000 & 3000 \\
MEP coeff estimate & -0.014 & 0.034 & -0.006 & -0.077 & -0.072 & 0.010 \\
T-statistic & -1.650 & 1.930 & -0.530 & -3.840 & -1.980 & 0.180 \\
\hline
\end{tabular}

\subsection{Survival Analysis}

The Cox model is constrained to follow the proportional hazards assumption (which means that the hazard ratio is constant across time, not across observations). We confirmed in our preliminary testing that the data do not violate this assumption, which means there was no significant difference in the rate of change in the survival probabilities over time between establishments as a whole. However, the evidence suggests that there were significant differences in the survival probabilities for establishments that did and did not receive MEP services in the 19972007 period. Both models that were estimated come to the same conclusion about establishment survival being positively influenced by receipt of MEP assistance.

The results of the Cox model showed that establishments receiving MEP services had a significantly higher likelihood of surviving (i.e., MEP extension services had a significant and negative impact on establishment death rates). Put another way, MEP assistance increased the survival probabilities of establishments from 1997 to 2007. As for subsets of the data, extension services did not improve survival probabilities in the 1997 to 2002 period, which is consistent with what we observed in the productivity equation. But, extension services did improve survival 
probabilities in the 2002 to 2007 period. Using the results of the Cox model in Table 9, the hazard ratio of 0.82 suggests that MEP client establishments are $18 \%$ less likely to die compared to nonclients and controlling for other factors.

Also, the logit model results reinforce the Cox model results. Table 9 also shows that MEP clients have a statistically significant and lower probability of death (i.e., higher probability of survival) across the 1997 to 2007 period. $^{12}$

Table 9. Weibull and Logit Regression Estimates

\begin{tabular}{c|ccc|ccc}
\hline & \multicolumn{3}{|c|}{ Weibull Model } & \multicolumn{3}{c}{ Logit Model } \\
Variable & Hazard Ratio & Z-statistic & Prob. & Estimate & Z-statistic & Prob. \\
\hline Constant & $3.55 E-010$ & -178.13 & 0.00 & -0.01 & -2.16 & 0.03 \\
Estab Age & 0.67 & -166.70 & 0.00 & -0.02 & -70.00 & 0.00 \\
VA97 & 1.00 & 1.41 & 0.15 & --- & --- & --- \\
VA02 & 1.00 & -0.70 & 0.48 & --- & --- & --- \\
VA07 & 1.00 & 1.66 & 0.09 & --- & --- & --- \\
TE97 & 1.00 & 23.63 & 0.00 & --- & --- & --- \\
TE02 & 1.00 & 8.78 & 0.00 & --- & --- & --- \\
TE07 & 0.99 & -37.78 & 0.00 & --- & --- & -- \\
MEP Customer & 0.82 & -3.92 & 0.00 & -0.54 & -18.56 & 0.00 \\
Min Distance & 1.00 & 2.83 & 0.01 & & & \\
\hline P & 9.47 & & & Pseudo R2 & 0.01 & \\
1/p & 0.10 & & Rounded) & 452,000 & \\
N (Rounded) & 161,000 & & LogL & $-301,235$ & \\
LogL & $-36,803$ & & & & \\
\hline
\end{tabular}

\footnotetext{
${ }^{12}$ The variable that measures the minimum distance to an MEP office was operationalized using a SAS routine that computes latitude and longitude coordinates. We then generated the minimum distance between an establishment and the nearest MEP office using the standard Haversine formula, which accounts for the circular nature of geographic distance.
} 


\section{CONCLUSIONS}

Overall, the results portray a nuanced picture of the ways in which MEP services impact productivity, sales, employment, and establishment survival when compared with a matched nonclient control group. Through the econometric approaches undertaken in the study, we were able to disaggregate the effect of MEP services across establishment size, industry, and type of project. We find, regardless of econometric model specification, that MEP clients with 1 to 19 employees have statistically significant and higher levels of labor productivity growth than non-clients in this employee size range. In contrast, the extension variable is not positively associated with higher productivity growth for MEP clients with 20 or more employees, and the coefficients on the extension variable are negative and significant for the largest MEP clients. Establishments in the medium-size employment category are often targeted as the most appropriate for MEP services, whereas the findings from this study-as well as the earlier Ordowich et al. (2012) studyunderscore the MEP's greater propensity to affect positive change in smaller establishments.

We observed significant productivity differences associated with MEP services by broad sector, with higher impacts over the 2002-2007 time period in the durable manufacturing sector than in the non-durable manufacturing sector. One interpretation of this result is that MEP services may be particularly oriented to durable goods establishments such as machine shops, component suppliers, and other durable products manufacturers. Under this interpretation, it might not be surprising that these types of firms would be most apt to have positive growth in value-added per employee as a result of MEP services because MEP services are most suitable for their needs. It might also be plausible to suggest that the broader durable goods industry group fared better than the non-durable goods industry group over this time period (2002-2007), and this higher performance spilled over into better MEP client performance for this group. However, this 
interpretation is not supported by data from the U.S. Bureau of Economic Analysis. Durables had slower growth in current value-added per employee than non-durables during these two time periods. Change in value-added per employee for durables from $1997-2002$ was $-0.3 \%$ versus $0.4 \%$ for non-durables and from $2002-2007$ it was $1.0 \%$ versus $1.2 \%$ for non-durables. ${ }^{13}$ Therefore, it is particularly noteworthy that MEP clients in the durables sector saw positive and sig nificant grow th in value-added per employee given these overall industry group trends. In addition, while quantitative changes in value-added or sales are important measures of program impact, many small firms cannot readily provide this information (Shapira et al., 2004).

The results also show that establishments receiving MEP assistance have a statistically significant and higher probability of survival than those that do not receive MEP assistance. The longer-term survival of a manufacturing enterprise can also be an outcome of program intervention. In an era of downward or slow-grow th economic cycles, the ability to show that an establishment is sufficiently competitive to survive as a result of MEP services may be an additional measure of program effects.

Our findings are subject to several caveats and limitations. First, while we had a similar match rate to the previous Ordowich et al. study, it was a bit disappointing. However, manual inspection of our matches makes us confident that our matches are accurate. Further inspection of the employment distribution of these matches suggested that we were less able to match smaller firms with fewer than 20 employees and larger firms with more than 500 employees. ${ }^{14}$ Of course, if each MEP client had an EIN associated with it, this information would make the matches more reliable, but attaching an EIN to each MEP client would be extremely onerous for center reporting

\footnotetext{
${ }^{13}$ Value-Added by Industry. Accessed November 17, 2014 from http:/ /www.bea.gov.

14 These results were not released in the Census Bureau disdosure process.
} 
staff. We emphasize that the effect of this match rate is to bias results towards zero (because of the possibility that unmatched clients appear in the comparison group). Thus, the finding that MEP assistance is positively but not significantly associated with higher productivity, especially given the difference of means tests results, is potentially attributable to the presence of MEP clients in the control group that were not successfully matched during that phase of our research.

We suspect that future match rates, especially of smaller firms, could be improved through even greater manual curation of the entity resolution (record-matching) process. By sampling nonmatched properties and employing the power of human pattern-matching, a set of additional business rules can be added to the existing fuzzy-matching techniques currently available in the matching programs. The findings from manual curation would help address the idiosyncrasies present in these datasets and, therefore, increase match rates. While resource-intensive from a timeperspective, building a better understanding of the entity relationships between these varied Census Bureau datasets could create benefits well outside of any single future study.

Second, this analysis was not able to fully address self-selection bias. While we were able to find some instruments that worked in one of the time periods, the two-stage model that incorporated these instruments produced inconclusive results. It seems that the two subsequent efforts to replicate Jarmin's (1999) initial analysis (namely Ordowich et al. and the present study) have been unable to fit his selection model. This difficulty is probably due to the lack of utility of MEP center office locations in distinguishing clients from non-clients in the context of the rollout of MEP into a national network with systemwide access to extension specialists. Access to MEP center offices was more limited in the pre-national system time period of Jarmin's study. More work could be done in this area. It has been suggested that small sample tests of productivity differences between served and unserved establishments in the same firm or enterprise group could provide 
another perspective on the selection bias issue. However, good quality MEP client data would be needed for this type of analysis and the assumption of no spillover effects from sharing information or lessons learned between assisted and unassisted establishments in the same firm or enterprise group would have to be valid.

Jarmin's study also did not investigate differences in service characteristics. These were investigated as separate variables in the Ordowich et al. study, which examined the effects of number of projects, project hours, substance categories, and delivery methods; however, the results were inconclusive. Our current study focused on substance categories and did find differences between "top-line" and "bottom-line" emphases. One could presumably look at the other attributes of services, but they likely interact with one another in complex ways. Our focus on substance categories provides an interpretable and actio nable approach as a reasonable starting point, but more could be done to examine the effectiveness of MEP services on value-added per employee as well as other outcome variables. Still, further research to determine the characteristics of MEP clients that select into certain substance categories (i.e., request certain types of services) and whether there is a point of diminishing returns related to certain types of services would be helpful to understand the relationship between service substance and firm performance.

Finally, the Census Bureau data offer a rare and extremely valuable resource for examining the effects of the program on establishment outcomes. It is limited in the types of outcome data that can be modeled, however. Qualita tive outcomes, such as use of advanced technology and techniques and measures of innovation, are not captured in Census Bureau data. Innovation measures are available in other associated datasets such as the Business R\&D and Innovation Survey (BRDIS), but small manufacturers are not well represented in that survey. 
The Census Bureau approval and disclosure processes are lengthy and involve much administrative follow-up. In addition, running the econometric models within the Research Data Center framework requires strong computing skills to process the data and perform these analyses. These limitations should be taken into consideration in planning the timeframe and budget for future analyses. 


\section{REFERENCES}

Angrist, J., and Pischke, J-S. (2009). Mostly Harmless Econometrics, Princeton University Press: Princeton, NJ.

Griliches, Z. (1996). "The Discovery of the Residual: A Historical Note," Journal of Economic Literature, American Economic Association 34(3): 1324-1330.

Heckman, J. J. (1976). "The common structure of statistical models of truncation, sample selection and limited dependent variables and a simple estimator for such models," Annals of Economic and Social Measurement 5(4): 475-492.

Hosemer, D.W. and Lemeshow, S. (1989). Applied Logistic Regression. New York: John Wiley.

Jarmin, R.S. (1999). "Evaluating the Impact of Manufacturing Extension on Productivity Growth," Journal of Policy Analysis and Management 18 (1): 99-119.

Mundlak, Y. (1961). "Empirical Production Function Free of Management Bias,” Journal of Farm Economics 43(1): 44-56.

National Research Council. (2013). 215t Century Manufacturing: The Role of the Manufacturing Extension Partnership. Board on Science, Technology, and Economic Policy. Washington, DC: The National Academies Press. [http://www.nap.edu/catalog/18448/21st-century-manufacturingthe-role-of-the-manufacturing-extension-partnership]

Ordowich, C., Cheney, D., Youtie, J., Fernandez Ribas, A., and Shapira, P. (2012). Evaluating the Impact of MEP Services on Establishment Performance: A Preliminary Empirical Investigation. U.S. Census Bureau Center for Economic Studies Paper No. CES-WP-12-15. [http://www2.census.gov/ces/wp/2012/CES-WP-12-15.pdf]

Shapira, P. Youtie, J., Wang, J., Hegde, D., Cheney, D., Franco, Q., and Mohapatra, S. (2004). Assessing the Value of Information and its Impact on Productivity in Small and Midsize Manufacturers. 
Georgia Institute of Technology and SRI International.

[http://csted.sri.com/sites/default/files/reports/NIST_Information Productivity.pdf]

Shapira, P., and Youtie, J. (2014). Impact of Technology and Innovation Advisory Services. Nesta Working Paper 13/19. London: Nesta. [http://www.nesta.org.uk/publications/impact-technology-andinnovation-advisory-services]

Solow, R. (1957). "Technical Change and the Aggregate Production Function," Review of Economics and Statistics 39: 312-320.

U.S. Bureau of Economic Analysis. (2014). Value-Added by Industry. [http://www.bea.gov/industry/gdpbyind data.htm]

Youtie, J. (2013). “An Evaluation of the MEP: A Cross-Study Analysis,” Appendix B, pp. 390-427, in: National Research Council (2013). 21 ${ }^{\text {st }}$ Century Manufacturing: The Role of the Manufacturing Extension Partnership. Board on Science, Technology, and Economic Policy. Washington, DC: The National Academies Press. [http://www.nap.edu/catalog/18448/21st-centurymanufacturing-the-role-of-the-manufacturing-extension-partnership] 


\section{APPENDIX}

\section{Appendix 1. Variables Used in the Analyses}

\begin{tabular}{|c|c|c|c|}
\hline Variable & Description & Source & Calculation \\
\hline \multicolumn{4}{|c|}{ Outcome Variables } \\
\hline$\frac{Y_{i t}}{L_{i t}}$ & $\begin{array}{l}\text { Value-added per employee } \\
\text { at establishment } i \text { in period } t\end{array}$ & $\mathrm{CMF}$ & $\begin{array}{l}\text { - Y: Value-added in } 2007 \\
\text { dollars } \\
\text { - L: number of production } \\
\text { workers }\end{array}$ \\
\hline$\frac{S_{i t}}{L_{i t}}$ & $\begin{array}{l}\text { Sales per employee at } \\
\text { establishment } i \text { in period } t\end{array}$ & $\mathrm{CMF}$ & $\begin{array}{l}\text { - Y: Value of shipments in } \\
2007 \text { dollars } \\
\text { - L: number of production } \\
\text { workers }\end{array}$ \\
\hline Surv1 & $\begin{array}{l}\text { Firm survival from one } \\
\text { period } t \text { to period } t+1\end{array}$ & LBD & $\begin{array}{l}\text { Coded as } 1 \text { if establishment is } \\
\text { not operating and } 0 \text { if } \\
\text { establishment is operating } \\
\text { (used in Cox model) }\end{array}$ \\
\hline \multicolumn{4}{|c|}{ Treatment Variables } \\
\hline$E x t_{i, X->Y, Z}$ & $\begin{array}{l}\text { Binary variable for whether } \\
\text { a plant received MEP } \\
\text { services between years } X \\
\text { and } Y^{15}\end{array}$ & NIST-MEP & $\begin{array}{l}\text { Coded as } 1 \text { for received } \\
\text { services (all records from } \\
\text { NIST MEP) and } 0 \text { for all } \\
\text { other establishments (control } \\
\text { group from LBD/CMF) }\end{array}$ \\
\hline Substance $_{i}$ & $\begin{array}{l}\text { Substance of MEP } \\
\text { treatment }\end{array}$ & NIST-MEP & $\begin{array}{l}\text { Calculated based on summary } \\
\text { statistics by MEP center }\end{array}$ \\
\hline CumHours $_{i, X->Y, Z}$ & $\begin{array}{l}\text { The cumulative hours of } \\
\text { services received by } \\
\text { establishment } i \text { between } \\
\text { years } X \text { and } Y \text { on service } \\
\text { type } Z\end{array}$ & NIST-MEP & $\begin{array}{l}\text { Aggregated from NIST MEP } \\
\text { data based on number of } \\
\text { hours (center/affiliate) } \\
\text { devoted to services of } \\
\text { specified type over the time } \\
\text { period of interest }\end{array}$ \\
\hline \multicolumn{4}{|c|}{ Control Variables } \\
\hline$L_{i t}$ & $\begin{array}{l}\text { Number of employees and } \\
\text { production workers at } \\
\text { establishment } i \text { in period } t\end{array}$ & $\mathrm{LBD} / \mathrm{CMF}$ & $\begin{array}{l}\text { Total number of employees; } \\
\text { total number of production } \\
\text { workers }\end{array}$ \\
\hline$\frac{K_{i t}}{L_{i t}}$ & $\begin{array}{l}\text { Capital to labor ratio for } \\
\text { establishment } i \text { in period } t\end{array}$ & $\mathrm{CMF}$ & $\begin{array}{l}\text { - K: total capital expenditures } \\
\text { expressed in } 2007 \text { dollars } \\
\text { - L: number of production }\end{array}$ \\
\hline
\end{tabular}

\footnotetext{
15 Analysis by different time periods conducted to gauge how results change over time. Variables X and Y cover different time periods (1997 to 2002, 2002 to 2007, and 1997 to 2007).
} 


\begin{tabular}{|c|c|c|c|}
\hline Variable & Description & Source & Calculation \\
\hline & & & workers \\
\hline NAICS $_{\mathrm{i}}$ & $\begin{array}{l}\text { The five digit NAICS code } \\
\text { for establishment } i \text {, coded } \\
\text { into dummies for durables } \\
\text { and nondurables }\end{array}$ & $\mathrm{CMF}$ & $\begin{array}{l}\text { Directly from database; also } \\
\text { computed 2-digit sector } \\
\text { identifier and 3-digit subsector } \\
\text { identifier }\end{array}$ \\
\hline MinDist $_{i j}$ & $\begin{array}{l}\text { A continuous variable that } \\
\text { measures the distance of } \\
\text { establishment } i \text { to nearest } \\
\text { MEP center } j\end{array}$ & $\begin{array}{l}\text { SSEL/ } \\
\text { NIST MEP }\end{array}$ & $\begin{array}{l}\text { Use address from SSEL and } \\
\text { center data from NIST MEP } \\
\text { to identify the closest center } \\
\text { to each establishment in the } \\
\text { dataset }\end{array}$ \\
\hline InitProd $_{i}$ & $\begin{array}{l}\text { Productivity of } \\
\text { establishment } i \text { in } 1997\end{array}$ & CMF & $\begin{array}{l}\text { Value-added in } 1997 \text { for } \\
\text { establishment } i\end{array}$ \\
\hline PrevSales $_{\mathrm{i}}$ & $\begin{array}{l}\text { Previous (1992-1997) sales } \\
\text { grow th of establishment } i\end{array}$ & CMF & $\begin{array}{l}\text { Use CMF data from } 1992 \text { to } \\
1997 \text { to calculate previous } \\
\text { sales growth }\end{array}$ \\
\hline InitCapInt $_{i}$ & $\begin{array}{l}\text { Capital intensity level of } \\
\text { establishment } i \text { in } 1997\end{array}$ & CMF & $\begin{array}{l}\text { Capital to labor ratio for } \\
\text { establishment } i \text { in } 1997\end{array}$ \\
\hline Emp_group $_{i}$ & $\begin{array}{l}\text { Dummy variables for } \\
\text { different plant sizes } \\
\text { (number of employees) of } \\
\text { establishment } i \text { in } 2007\end{array}$ & LBD & $\begin{array}{l}\text { Number of employees in } 2007 \\
\text { in categories }\end{array}$ \\
\hline \multicolumn{4}{|c|}{ Instrumental Variables } \\
\hline Rurality $_{\mathrm{i}}$ & $\begin{array}{l}\text { Rural-Urban Continuum } \\
\text { Codes, } 2003,(1=\text { counties } \\
\text { with } 1+\text { million population, } \\
\ldots, 9=\text { completely rural } \\
\text { counties with less than } 2,500 \\
\text { population, etc.) }\end{array}$ & $\begin{array}{l}\text { US Department } \\
\text { of Agriculture, } \\
\text { Economic } \\
\text { Research Service }\end{array}$ & $\begin{array}{l}\text { Calculated based on county in } \\
\text { address data in SSEL }\end{array}$ \\
\hline$\overline{\text { Estab_age }_{\text {it }}}$ & Age of plant $i$ in period $t$ & LBD & $\begin{array}{l}\text { Calculated as } 2011 \text { minus } \\
\text { commencement date of } \\
\text { establishment }\end{array}$ \\
\hline
\end{tabular}

